FACTA UNIVERSITATIS

Series: Physical Education and Sport, Vol. 18, No 1, 2020, pp. 263 - 269

https://doi.org/10.22190/FUPES200102023B

Research article

\title{
BODY HEIGHT AND LORDOTIC POSTURE IN PRESCHOOL CHILDREN
}

\author{
UDC 615/67_005
}

\section{Zoran Bogdanović, Oliver Radenković, Izet Kahrović, Benin Murić, Omer Špirtović}

Department of Biomedical Science and Sport and Physical Education,

State University of Novi Pazar, Novi Pazar, Serbia

\begin{abstract}
The aim of this research is to determine the relation between body height and lordotic posture in preschool children. The survey was conducted on a sample of 149 participants ( 78 boys and 71 girls), aged 6 years ( \pm 6 months), of an average body height (BH) of $121.94 \pm 10.29 \mathrm{~cm}$, and the body mass $23.20 \pm 4.83 \mathrm{~kg}$ in the city of Kragujevac (Serbia). To assess lordotic posture, the Spinal Mouse was used, and all values above $30^{\circ}$ were treated as disorders in the lumbar region. In determining the size of the body, the Anthropometer by Martin is used, and the participants were divided into five groups by height. The existence and size of the correlation between the investigated areas was calculated by the use of the Pearson's chi-squared test and contingency coefficient as a measure of correlation. From the total sample, lortodic posture is present in $8.05 \%$ of the participants, and in terms of gender the incidence of poor posture is equal. Lordotic posture is most pronounced in the group of boys and girls with the BH of 123.01-127.00 $\mathrm{cm}$, followed by the group of girls with a BH of 121.51-123.00 cm. The lowest incidence of lordotic posture is determined in the groups with BH over $127.01 \mathrm{~cm}$, and below 119 $\mathrm{cm}$. The values of the Pearson's chi-squared test indicate a statistically significant correlation between lordotic posture and body height, with a significance 0.03.
\end{abstract}

Key words: Body Height, Lordotic Poor Posture, Incidence, Correlation, Preschool Children

\footnotetext{
Received January 20, 2020/ Accepted May 15, 2020

Corresponding author: Zoran Bogdanović

Department of Biomedical Science and Sport and Physical Education, State University of Novi Pazar, Vuka Karadžića bb, 36300 Novi Pazar, Serbia

Phone: + 38120317754 •E-mail: drzbog@gmail.com 


\section{INTRODUCTION}

Lumbar lordosis refers to an adaptation that ensures stability in humans when standing and walking (Wren et al., 2017). The habit of paying attention to whether children adopt correct body position in everyday life is lacking (Kot, Kokosz, \& Stencel-Gabriel, 2018), and as a consequence there is an increased incidence in lower back pain (Sadler, Spink, Ho, De Jonge, \& Chuter, 2017), and sleeping disorders (Lauridsen \& Hestbaek, 2013). By correcting the position of the body and placing the lumbar part in a neutral position, back pain can be reduced (Smith, O'Sullivan, \& Straker, 2008). Hence, poor postural status represents a growing, but still underestimated health problem that needs preventive and accurate diagnosis (Jorgić et al., 2016).

In lumbar lordosis the aligned position of the pelvis is compromised by the unequal contracting forces of the abdominal and hamstring muscles that should normally be in balance with each other (Jang, Koh, \& Han, 2013). Physical factors with the highest odds for lower back pain are a higher lumbar lordotic apex and an increased pelvis retroversion (Dolphens et al., 2016). According to Mulhearn \& George (1999) lumbar hyperlordosis is associated with the dysfunction of the transversus abdominis muscle. According to Malai, Pichaiyongwongdee, \& Sakulsriprasert (2015), hold-relax stretching of the iliopsoas muscle can be beneficial in reducing pain intensity, lumbar hyperlordosis and in improving the function of the transversus abdominis muscle in patients with excessive lumbar lordosis.

The sedentary lifestyle of today's adolescents consisting of a low level of physical activity, and a high level of computer oriented mental activities has reached epidemic proportions. Computer technology offers the young population a lot of entertainment and information resources, so that they spend more time in the so-called passive positions (sitting and lying). Such habits are distancing them from the natural need for movement and significantly reduce most of their physical and functional abilities. In a word, the children of today are playing in the fresh air less and are less physically active.

In terms of the above-mentioned the aim of this research is to determine the relation between body height and lordotic posture in preschool children.

\section{METHODS}

The research was conducted on a sample of 149 pre-schools children (78 boys and 71 girls), aged 6 years ( \pm 6 months) of the city of Kragujevac (Serbia), with an average body height of $121.94 \pm 10.29 \mathrm{~cm}$ (Mean \pm SD), and an average mass of $23.20 \pm 4.83 \mathrm{~kg}$ (Mean \pm SD). For the assessment of lordotic posture, non-invasive measurement methodology provided by the Spinal Mouse device was used (Idiag, Fehraltdorf, Switzerland, www.idiag.ch). The validity and reliability of the Spinal Mouse device are confirmed in previous studies (Mannion, Knecht, Balaban, Dvorak, \& Grob, 2004; Post \& Leferink, 2004; Forster, 2006; Guermazi et al., 2006).

Lumbar angulation in the sagittal plane was evaluated in a standing position. In order to classify the level of the disorder by category, the values determined by Cobb were used. Angulation of $15-30^{\circ}$ is considered normal, and all values above $30^{\circ}$ are treated as disorders in the lumbar region.

Body height is determined according to the methodology recommended by the International Biological Program (Weiner \& Lourie, 1969), and with usage of the Anthropometer by Martin. 
Children were divided into the following five groups according to body height $(\mathrm{BH})$ : 1) less than $119.00 \mathrm{~cm}$; 2) between $119.01-121.50 \mathrm{~cm}$; 3) between $121.51-123.00 \mathrm{~cm}$; 4) between $123.01-127.00 \mathrm{~cm}$, and 5) more than $127.01 \mathrm{~cm}$.

Standard descriptive parameters (mean, minimum score, maximum score, standard deviation) were used. Pearson's chi-squared test $\left(\mathrm{H}^{2}\right)$ with a significance level of the correlation set at $\mathrm{p} \leq 0.05$ was calculated by using the statistical package for data analysis SPSS, version 12 .

\section{RESULTS}

Descriptive parameters of the postural status in relation to gender, as well as values of Pearson's chi-squared test, the contingency coefficient and the significance are presented in Table 1.

Table 1 Lordotic posture in relation to gender

\begin{tabular}{|c|c|c|c|c|}
\hline \multirow[t]{2}{*}{ Postural status } & & \multicolumn{2}{|c|}{ Gender } & \multirow[t]{2}{*}{ Total } \\
\hline & & Boys & Girls & \\
\hline \multirow{3}{*}{ Good posture } & Count & 72 & 65 & 137 \\
\hline & $\%$ & 92.31 & 91.55 & \\
\hline & $\%$ of Total & 48.32 & 43.62 & 91.95 \\
\hline \multirow{3}{*}{$\begin{array}{l}\text { Lordotic posture (the } \\
\text { deviation is larger than } 30^{\circ} \text { ) }\end{array}$} & Count & 4 & 6 & 10 \\
\hline & $\%$ & 5.13 & 8.45 & \\
\hline & $\%$ of Total & 2.68 & 4.03 & 6.71 \\
\hline \multirow{3}{*}{$\begin{array}{l}\text { Lordotic posture (the } \\
\text { deviation is larger than } 40^{\circ} \text { ) }\end{array}$} & Count & 2 & 0 & 2 \\
\hline & $\%$ & 2.56 & 0 & \\
\hline & $\%$ of Total & 1.34 & 0 & 1.34 \\
\hline \multirow{2}{*}{ Total } & Count & 78 & 71 & 149 \\
\hline & $\%$ of Total & 52.35 & 47.65 & 100 \\
\hline
\end{tabular}

Of the total sample of participants, lordotic posture was present in $8.05 \%$ of the participants, and the incidence of poor posture by gender was uniform.

The values of Pearson's chi-squared test (2.43) and the contingency coefficient $(0.13)$ show an absence of statistically significance between lordotic posture and gender in the participants, with a significance of 0.30 .

Descriptive parameters of the postural status in relation to gender and body height groups, as well as the values of Pearson's chi-squared test, the contingency coefficient and the significance are presented in Table 2.

Observed in terms of the $\mathrm{BH}$ groups of participants, lordotic posture is most frequent in the group of BH 123.01-127.00 cm, followed by the group of girls of BH 121.51-123.00 cm. The lowest incidence of poor posture was determined in the group of participants of BH of more than $127.01 \mathrm{~cm}$, as well as in the group of BH of less than $119 \mathrm{~cm}$.

Concerning the lordotic posture of the boys, the largest incidence is determined in the group of BH 123.01-127.00 cm and the group of participants with $\mathrm{BH}$ of over $127.01 \mathrm{~cm}$. In the other $\mathrm{BH}$ groups, there were no cases of scoliotic posture. In the sample of girls, lordotic posture is most frequent in the group of $\mathrm{BH} 121.51-123.00 \mathrm{~cm}$, and the group of 
BH 123.01-127.00 cm. There were no cases of the scoliotic posture at all in the groups of $\mathrm{BH}$ up to $119.00 \mathrm{~cm}$ and $\mathrm{BH}$ over $127.01 \mathrm{~cm}$.

Table 2 Body height and lordotic posture in relation to gender

\begin{tabular}{|c|c|c|c|c|c|c|c|}
\hline \multirow[b]{3}{*}{ Body height } & & \multicolumn{6}{|c|}{ Lordotic posture } \\
\hline & & \multicolumn{2}{|c|}{$\begin{array}{c}\text { Good } \\
\text { posture }\end{array}$} & \multicolumn{2}{|c|}{$\begin{array}{c}\text { Deviation } \\
\text { is larger than } 30^{\circ}\end{array}$} & \multicolumn{2}{|c|}{$\begin{array}{c}\text { Deviation } \\
\text { is larger than } 40^{\circ}\end{array}$} \\
\hline & & Boys & Girls & Boys & Girls & Boys & Girls \\
\hline \multirow{3}{*}{$\leq 119.00 \mathrm{~cm}$} & Count & 14 & 20 & 0 & 0 & 0 & 0 \\
\hline & $\%$ & 19.44 & 30.77 & 0 & 0 & 0 & 0 \\
\hline & $\%$ of Total & 17.95 & 28.17 & 0 & 0 & 0 & 0 \\
\hline \multirow{3}{*}{$119.01-121.50 \mathrm{~cm}$} & Count & 16 & 10 & 0 & 1 & 2 & 0 \\
\hline & $\%$ & 22.22 & 15.38 & 0 & 16.67 & 100 & 0 \\
\hline & $\%$ of Total & 20.51 & 14.08 & 0 & 1.41 & 2.56 & 0 \\
\hline \multirow{3}{*}{$123.01-127.00 \mathrm{~cm}$} & Count & 13 & 14 & 0 & 3 & 0 & 0 \\
\hline & $\%$ & 18.06 & 21.54 & 0 & 50 & 0 & 0 \\
\hline & $\%$ of Total & 16.67 & 19.72 & 0 & 4.23 & 0 & 0 \\
\hline \multirow{3}{*}{$\geq 127.01 \mathrm{~cm}$} & Count & 14 & 10 & 3 & 2 & 0 & 0 \\
\hline & $\%$ & 19.44 & 15.38 & 75 & 33.33 & 0 & 0 \\
\hline & $\%$ of Total & 17.95 & 14.08 & 3.85 & 2.82 & 0 & 0 \\
\hline \multirow{3}{*}{$\geq 127.01 \mathrm{~cm}$} & Count & 15 & 11 & 1 & 0 & 0 & 0 \\
\hline & $\%$ & 20.83 & 16.92 & 25 & 0 & 0 & 0 \\
\hline & $\%$ of Total & 19.23 & 15.49 & 1.28 & 0 & 0 & 0 \\
\hline \multirow{2}{*}{ Total } & Count & 72 & 65 & 4 & 6 & 2 & 0 \\
\hline & $\%$ & 92.31 & 91.55 & 5.13 & 8.45 & 2.56 & 0 \\
\hline
\end{tabular}

Legend: Boys: Pearson's Chi-Squared Test 14.59; Contingency coefficient 0.40; Significance $p=0.07$; Girls: Pearson's Chi-Squared Test 5.77; Contingency coefficient 0.25 ; Significance $\mathrm{p}=0.22$

The values of Pearson's chi-squared test of 14.59 in boys and of 5.77 in girls, as well as the contingency coefficient of 0.40 in boys and 0.25 in girls, with a significance of 0.07 in boys and 0.22 in girls, indicate the absence of a statistically significant difference between $\mathrm{BH}$ and lordotic posture of participants observed in terms of gender and height groups.

\section{DISCUSSION}

The juvenile period (ages 4 to 7 ) is a critical period in the growth and development when deformities such lordotic posture are formed (Protić-Gava, Krsmanović, Jevtić, Kadović, \& Romanov 2009).

Proper posture is evident in a decreasing number of children (Đokić \& Stojanović, 2010; Ludwig, Mazet, Mazet, Hammes \& Schmitt, 2016). The analysis of all obtained results shows the appearance of lordotic posture associated with body height (Bogdanović \& Milenković, 2008; Bogdanović \& Marković, 2009; Trajković \& Nikolić, 2008). The results obtained in our research do not have statistical significance, but show a tendency of lordotic posture with increasing height. Petrović, Puzović, Đorđević, Obrenović and Jakovljević (2012) conclude that hyperlordosis is present in $9.2 \%$ of cases, and that gender and age do not significantly affect the prevalence of this deformity. 
The shift in the results of the spinal column parameters depending on the age category can be explained by the fact that the reduction of physical activity of children with the beginning of preschool and school obligations leads to a muscle imbalance which is directly related to spinal deformity and lordosis. Improper and long sitting in front of the TV, the computer, improper carrying of a school backpack, are also reasons for the development of spinal deformities, as well as hunched standing. In order to create an equilibrium position, there is a compensatory movement of the pelvis that leans forward, which leads to an increase in lumbar lordosis. These movements can also lead to the development of other spinal deformities (Andrašić, Milić, Cvetković, Ujsasi, \& Orlić, 2017).

The research of other authors, local and foreign, indicate similar tendencies between $\mathrm{BH}$ and certain postural disorders, both in the preschool population and later in adolescence.

According to the results of Protić-Gava et al. (2013) on a total sample of 61 participants, aged 8.52 years, lordotic posture prevailed as the most common in: $41 \%$ of children was with minor deviations and $13.1 \%$ with larger deviations. Similar results, in a population of children aged 6 to 7 were found by Romanov, Stupar, Međedović, and Brkin (2014): the most common was lordotic posture, $41.31 \%$ in male participants and $36.66 \%$ in female participants. Gh, Alilou, Ghafurinia, \& Fereydounnia (2012) point out that the prevalence of lordosis is $22.6 \%$ among children aged 5 to 20 . Lordosis increases by $6^{\circ}$ from the age of 5 to 15 (Widhe, 2001).

Simov, Minić and Stojanović (2011) determined the manifestation of the lordotic posture in $2.07 \%$ of preschool children.

Korovljev, Marinković, Roška, and Madić (2015) point out that spinal deformities significantly increase and appear in children of a younger school age compared to preschool children, emphasizing the negative effect of the significantly heavier school bags than recommended ( $10 \%$ of the total weight of the child).

\section{CONCLUSION}

The results obtained in this research, observed on the total sample, indicate that lordotic posture was most expressed in the group of boys and girls of BH 123.01-127.00 $\mathrm{cm}$, followed by the group of girls of BH 121.51-123.00 cm. Special attention is required in the prevention, i.e., in the adequate education of the staff of preschool institutions.

\section{REFERENCES}

Andrašić, S., Milić, Z., Cvetković, M., Ujsasi, D., \& Orlić, D. (2017). Relations between biomechanical parameters and static power of arms in children with disturbed posture. Sport Mont, 15(1), 23-26.

Bogdanović, Z., \& Milenković, S. (2008). Morphological space and postural disorders in younger school children. Journal of the Anthropological Society of Serbia, 43, 371-378.

Bogdanović, Z., \& Marković, Ž. (2009). Relations between morphological characteristics and postural status of elementary school students. Sport Science, 2(2), 102-106.

Dolphens, M., Vansteelandt, S., Cagnie, B., Vleeming, A., Nijs, J., Vanderstraeten, G., et al. (2016). Multivariable modeling of factors associated with spinal pain in young adolescence. European Spine Journal, 25(9), 2809-2821.

Đokić, Z., \& Stojanović, M. (2010). Morfološke karakteristike i posturalni status dece od 9 do 12 godina na podruĉju Sremske Mitrovice (Morphological characteristics and postural status of children aged 9 to 12 years in Sremska Mitrovica). Opšta medicina, 16 (1-2), 41-49. In Serbian 
Forster, F. (2006). Haltongsauffálligkeit leistungsofientiefter Sportkletterer (Attitude of performance-oriented sports climbers Munchen: Institute for Sport Science and Sport, University of the Bundeswehr. In German

Gh, M. E., Alilou, A., Ghafurinia, S., \& Fereydounnia, S. (2012). Prevalence of faulty posture in children and youth from a rural region in Iran. Biomedical Human Kinetics, 4(1), 121-126.

Guermazi, M., Ghroubi, S., Kassis, M., Jazari, O., Keskes, H., Kessomtini, W., et al. (2006).. Validity and reliability of Spinal Mouse to assess lumbar flexion. Annales de Readaptation et de Medecine Physique, 49(4), 172-177.

Jang, J., Koh, E., \& Han, D. (2013). The effectiveness of passive knee extension exercise in the sitting position on stretching of the hamstring muscles of patients with lower back pain. Journal of Physical Therapy Science, 25(4), 501-504.

Jorgić, B., Milenković, M., Ždrale, S., Milenković, S., Stanković, R., \& Bubanj, S. (2016). Spinal cord posture in the sagittal plane among young schoolchildren residing in the area of Knjaževac. Facta Universitatis Series Physical Education and Sport, 13(2), 311-318.

Korovljev, D., Marinković, D., Roška, M., \& Madić, D. (2015). Posturalni status kičmenog stuba kod dečaka uzrasta od 4-13 godina (Postural status of the spinal column in boys aged 4-13). In Z. Grgantov, S. Krstulović, J. Paušić, T. Bavčević, D. Čular, A. Kezić, \& M. Miletić (Eds.). Proceedings of the 5th International Scientific Conference „Contemporary Kinesiology”, (pp. 425-434). Split: Faculty of Kinesiology, University of Split

Kot, K., Kokosz, M., \& Stencel-Gabriel, K. (2018). The influence of four-month exercises during lessons on body posture in children in younger school age. Journal of Education, Health and Sport, 8(9), 756-767.

Lauridsen, H.H., \& Hestbaek, L. (2013). Development of the young spine questionnaire. BMC Musculoskeletal Disorders, 14(1), 185.

Ludwig, O., Mazet, C., Mazet, D., Hammes, A., \& Schmitt, E. (2016). Changes in habitual and active sagittal posture in children and adolescents with and without visual input-implications for diagnostic analysis of posture. Journal of clinical and diagnostic research: JCDR, 10(2), SC14.

Malai, S., Pichaiyongwongdee, S., \& Sakulsriprasert, P. (2015). Immediate effect of hold-relax stretching of iliopsoas muscle on transversus abdominis muscle activation in chronic non-specific low back pain with lumbar hyperlordosis. Journal of the Medical Association of Thailand, 98, S6-11.

Mannion, AF., Knecht, K., Balaban, G., Dvorak, J., \& Grob, D. (2004) A new skin-surface device for measuring the curvature and global and segmental ranges of motion of the spine: reliability of measurements and comparison with data reviewed from the literature. European Spine Journal, 13(2), 122-136.

Mulhearn, S., \& George, K. (1999). Abdominal muscle endurance and its association with posture and low back pain: an initial investigation in male and female elite gymnasts. Physiotherapy, 85(4), 210-216.

Petrović, J., Puzović, V., Đorđević, D., Obrenović, M., Medić, V., \& Jakovljević, V. (2012). The prevalence of spinal deformities in children aged 7-11 years. Medicinski časopis, 46(4), 187-190.

Post, R.B., \& Leferink, V.J. (2004). Spinal mobility: sagittal range of motion measured with the Spinal Mouse, a new non - invasive device. Archives of Orthopedic and Trauma Surgery, 124(3), 187-192.

Protić-Gava, B., Krsmanović, T., Jevtić, N., Kadović, V., \& Romanov, R. (2009). Postural disorders in sagittal plane and differences according to gender. Fizička kultura(Skopje), 37 (2), 134-137.

Protić-Gava, B., Šćepanović, T., \& Batez, M. (2013). Body posture in young schoolchildren in a novi sad elementary school. Resaarch in Kinesiology, 41(2), 146-149.

Romanov, R., Stupar, D., Međedović, B., \& Brkin, D. (2014). Posturalni status dece predškolskog uzrasta na teritoriji Novog Sada (Postural status of preschool children on the territory of Novi Sad). Tims. Acta, 8(2), 129-135. In Serbian

Sadler, S. G., Spink, M. J., Ho, A., De Jonge, X. J., \& Chuter, V. H. (2017). Restriction in lateral bending range of motion, lumbar lordosis, and hamstring flexibility predicts the development of low back pain: a systematic review of prospective cohort studies. BMC Musculoskeletal Disorders, 18(1), 179.

Simov, S.B., Minić, S.M., \& Stojanović, D. O. (2011). Učestalost pojave lošeg držanja tela i ravnih stopala kod dece predškolskog uzrasta. Apollinem Medicum et Aesculapium, 9(2), 5-8.

Smith, A., O'Sullivan, P., \& Straker, L. (2008). Classification of sagittal thoraco-lumbo-pelvic alignment of the adolescent spine in standing and its relationship to low back pain. Spine, 33(19), 2101-2107.

Trajković, S., \& Nikolić, M. (2008). Canonical relations between anthropometric measures and postural disturbances school children. Journal of the Anthropological Society of Serbia, 43, 379-385.

Weiner, J., \& Lourie, J. (1969). Human Biology, A Guide to Field Methods, International Biological Program. Blackwell Scientific Publications: Oxford-Edinburg.

Widhe, T. (2001). Spine: posture, mobility and pain. A longitudinal study from childhood to adolescence. European Spine Journal, 10(2), 118-123.

Wren, T. A., Aggabao, P. C., Poorghasamians, E., Chavez, T. A., Ponrartana, S., \& Gilsanz, V. (2017). Association between vertebral cross-sectional area and lumbar lordosis angle in adolescents. PloS one, 12(2). 


\section{VISINA TELA I LORDOTIČNO LOŠE DRŽANJE DECE PREDŠKOLSKOG UZRASTA}

Cilj ovog istraživanja je da se utvrdi odnos između visine tela i lordotično lošeg držanja dece predškolskog uzrasta. Istraživanje je sprovedeno na uzorku od 149 ispitanika (78 dečaka $i 71$ devojčica), uzrasta 6 godina ( \pm 6 meseci), prosečne telesne visine (BH) $121.94 \pm 10.29 \mathrm{~cm}$ i telesne mase $23.20 \pm 4.83 \mathrm{~kg}$, grada Kragujevca (Srbija). U proceni lordotičnog lošeg držanja korišćen je uređaj Spinal Mouse, a sve vrednosti iznad $30^{\circ}$ tretirane su kao poremećaji u lumbalnom delu kičmenog stuba. Za utvrđivanje visine tela korišćen je Antropometer po Martinu, a ispitanici su prema visini podeljeni u pet grupa. Postojanje i veličina korelacije između ispitivanih područja izračunati su korišćenjem Pearsonovog Hi kvadrat testa i koeficijenta kontingencije kao mere korelacije. Od ukupnog uzorka, lortodično držanje je zastupljeno u $8.05 \%$ ispitanika, a u odnosu na pol, incidenca lordotično lošeg držanja je jednaka. Lortodično loše držanje je najizraženije u grupi dečaka $i$ devojčica BH 123.01-127.00 cm, a sledi grupa devojčica $B H$ 121.51-123.00 cm visine. Najniža incidenca lordotičnog lošeg držanja utvrđena je u grupama BH preko $127.01 \mathrm{~cm}$ i ispod $119 \mathrm{~cm}$. Vrednosti Pearsonovog Hi kvadrata testa pokazuju statistički značajnu povezanost između lordotično lošeg držanja i BH, sa nivoom značajnosti od 003.

Ključne reči: telesna visina, lordotično loše držanje, učestalost, korelacija, predškolska deca 